\title{
Restraining the Growth of Total Spending
}

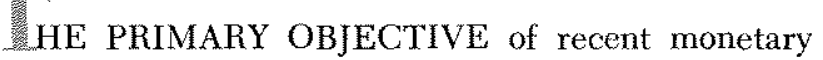
and fiscal actions is to slow the rapid rate of growth of total spending and thereby ease excessive pressure on resource utilization and prices. Total spending continues to outpace the growth of the economy's productive potential. Real product growth has moderated somewhat, but prices have shown no signs of decelerating. Stabilization actions since mid-1968 have had little restraining effect so far on total spending and prices.

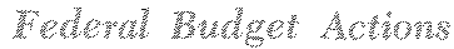

Fiscal policy, as represented by the high-employment budget, was very expansionary from mid 1965 to mid-1968. The high-employment budget averaged a $\$ 7.3$ billion rate of deficit during this period. Following passage of the Revenue and Expenditure Control Act in late June of 1968, the deficit in the highemployment budget declined sharply, moving to a significant surplus of over $\$ 5$ billion in the first quarter of 1969 . This compares with a deficit of $\$ 16$ billion in the second quarter of last year.

Any impact on spending and prices from the mid. 1968 fiscal action has been scarcely perceptible to date. Because added fiscal restraint does not appear to be forthcoming, future economic slowing from fiscal actions will have to be in the form of a lagged response to actions already taken. Recently announced budget plans indicate that the surcharge will be retained at the current level through 1969, but reduced to 5 per cent in early 1970. The Administration has also proposed that the investment tax credit be repealed, but the economic impact of such an action would probably be small in 1969 .
Recently revised plans suggest that Federal expenditures in the high-employment budget will increase at about a 4.4 per cent annual rate from first quarter to fourth quarter 1969. By comparison such expenditures rose at a 5.6 per cent annual rate from second quarter 1968 to first quarter 1969, and about a 15 per cent average rate from mid-1965 to mid-1968.

The effects of revenue and expenditure plans combine to yield an estimated $\$ 7$ billion annual rate of high-employment surplus for the rest of 1969. This rate of surplus represents a substantial improvement compared with the first half of 1968 rate of deficit of $\$ 14.5$ billion, but does not indicate added fiscal restraint in the last three quarters of 1969.

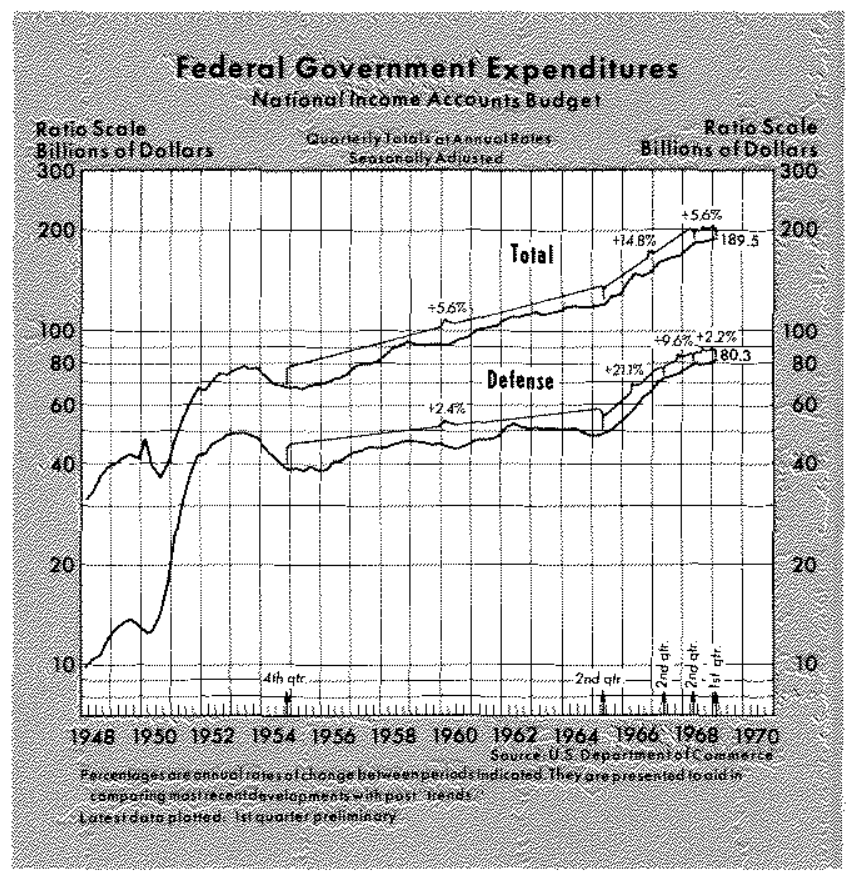




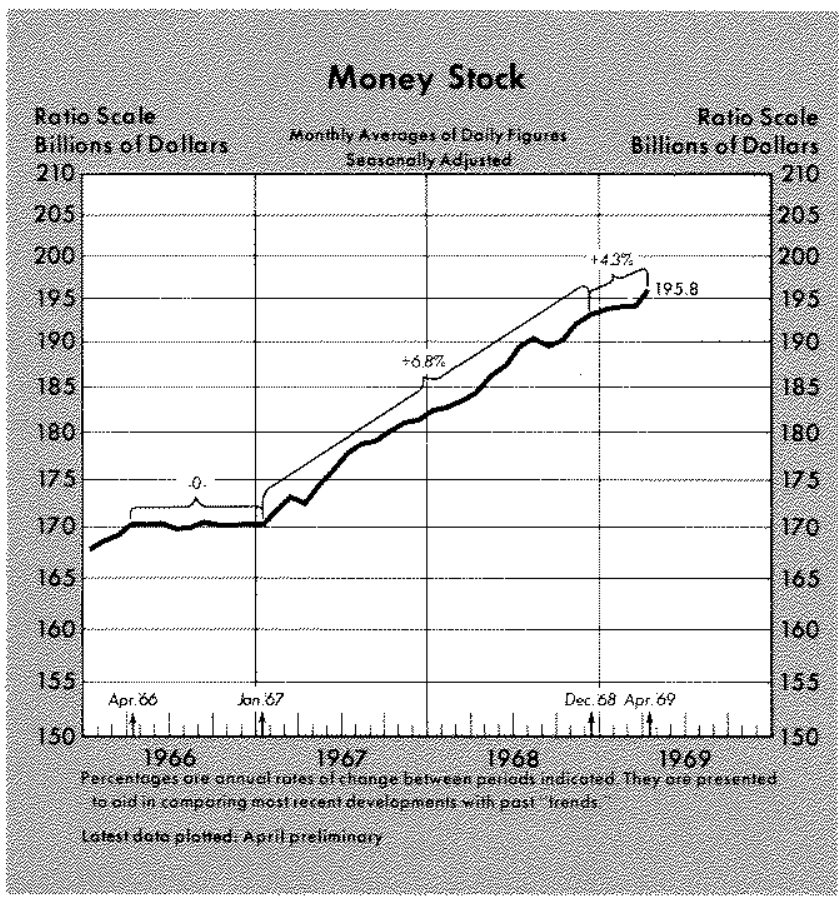

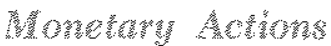

Most strategic monetary aggregates increased only moderately during the first quarter, but rose sharply in April. The monetary base increased at an annual rate of 3.3 per cent from December to April, about the same as the 1957-68 trend rate, but substantially slower than the 6.5 per cent increase in 1968. The money stock, consisting of private demand deposits and currency held by the public, grew at a 1.9 per cent annual rate during the first quarter, but increased sharply in April. The jump in money which occurred in early April appears to have been a temporary aberration in the data, with money rising at about a 2 per cent rate from December to carly May.

Certificates of deposit at large commercial banks have decreased sharply since the end of last year, compared with a 14 per cent increase during 1968. Regulation Q, which imposes ceilings on the interest rates banks are permitted to pay on time deposits, has, in the face of historically high market rates of interest, placed banks at a disadvantage in the competition for funds. A portion of the runoff of $\mathrm{CD}^{\prime} \mathrm{s}$ has been offset by the acquisition of Euro-dollars and the sale of loan participations by a number of large banks. The growth of other time and savings deposits has also slowed, increasing at a 3.2 per cent rate from December to April compared with an 8 per cent rise in the previous year.

The combined effects of monetary restraint and Regulation $Q$ in the first quarter were reflected in a leveling off of total bank credit, that is, total commercial bank loans plus investments. Bank credit expanded at an annual rate of more than 14 per cent during the second half of 1968, but slowed sharply to a 1.3 per cent rate of increase during the first quarter of this year. To the extent that funds have been channelled away from banks because of the rise of market interest rates relative to Regulation $Q$, the slowing of bank credit does not indicate monetary restraint.

Recent changes in the discount rate, the Federal Reserve lending rate to member banks, have brought this rate more in line with market interest rates. The discount rate was raised to $5 \frac{1}{2}$ per cent in December, after it had been lowered to 5//4 per cent last August. On April 4, the Federal Reserve raised the discount rate to 6 per cent and announced an increase in reserve requirements on demand deposits. Member bank borrowings from Federal Reserve banks have increased considerably since the first of the year, as market rates rose well above the discount rate. Borrowings averaged $\$ 920$ million in March, up from a $\$ 752$ million average in December. Since the April increase in the discount rate and in reserve requirements, borrowings have averaged $\$ 1.1$ billion.

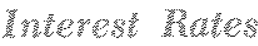

Strong demand for loans pushed market interest rates sharply upward from October through December, and the rise in some rates continued through April of this year. Three-month Treasury bill rates continued to advance in April, while long-term rates declined slightly. Interest rates on four-to six-month

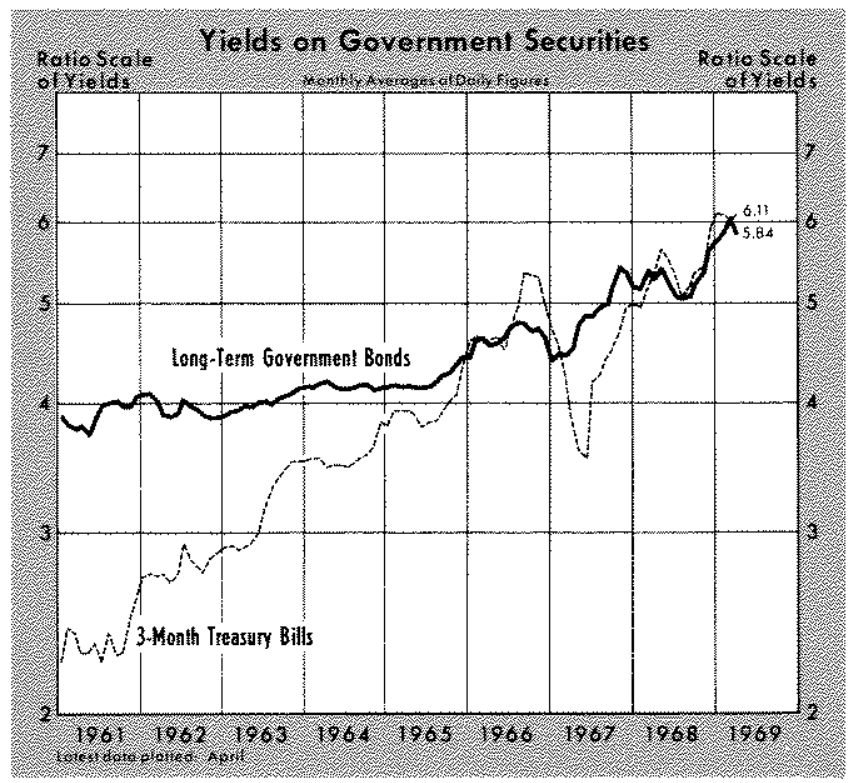


commercial paper averaged 7.13 per cent in late April, compared with 6.17 per cent in December and 5.80 per cent in October.

Interest rates on long-term Government securities resumed their upward movement from August of last year, rising from about 5 per cent to 6.05 per cent in March. Since then yields on these securities have declined, averaging 5.84 per cent in April. The average yield on highest grade corporate bonds was 6.89 per cent in April, up 40 basis points from the end of 1968, and 138 basis points higher than the average for 1967.

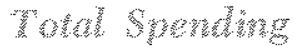

Total spending on goods and services rose at a 7.6 per cent annual rate from the third quarter of 1968 to the first quarter of 1969 , about the same as the rate for the preceding two years. Final sales, that is, total spending other than changes in inventories, increased at a 7.9 per cent rate in the past two quarters, also about the same as in the preceding two years.

Investment Spending - According to a recent Government survey of anticipated capital expenditures, such spending is expected to rise 14 per cent this year. By comparison, business spending for new plant and equipment increased 10.7 per cent in the year ending first quarter, well above the 5.3 per cent trend rate for 1957-1967.

The rate of inventory accumulation has remained low relative to rates in late 1967 . The ratio of inven-

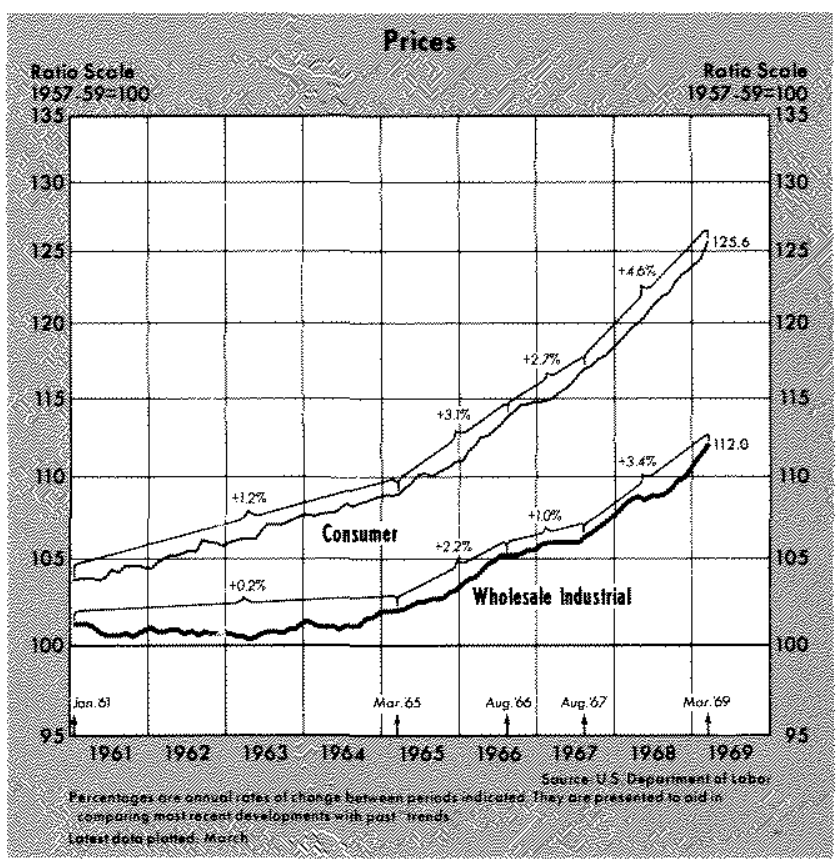

tory to sales was 1.54 in the first quarter, the same as in the previous quarter, but substantially below the average ratio of 1.58 for 1967 .

Despite rising interest rates, home building increased rapidly in the second half of 1968 , but has slowed in the early months of 1969 . The value of new residential construction (nonfarm) increased at a 28.9 per cent annual rate from July to December but has increased at a 6.6 per cent rate since December.

Consumer Spending-Consumer demand remained buoyant during the first quarter, increasing at an annual rate of 8.8 per cent, about the same as the 9 per cent rate of growth during the past year, but significantly greater than the 1961-67 trend rate of 6.6 per cent. The first quarter increase reflected increases in personal expenditures for durable goods at an 8.7 per cent annual rate, for nondurables at a 9.6 per cent rate, and for services at a 7.9 per cent rate. Retail sales rose at an 11.8 per cent rate in the first four months of this year compared to a 2.7 per cent rate of decline in the last five months of 1968 , and a 1961-67 trend rate of increase of 6.2 per cent.

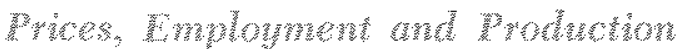

Prices have continued to accelerate. Wholesale industrial prices rose at a 6.7 per cent rate in the first three months of 1969 compared to a 2.6 per cent increase in the previous year and a 1.7 per cent annual rate from 1964 to 1967 . Consumer prices rose at a 6.3 per cent rate in the first quarter of 1969 , after rising at a 3.3 per cent rate from 1965 to 1968 and a 1.4 per cent rate for the 1957-65 period.

Domestic price inflation continues to undermine the U.S. foreign trade surplus. Imports, strengthened by the rapid growth in total demand and the growing price gap between foreign and domestic goods, have increased at an 8 per cent anmual rate since mid-1967 while exports have declined at a 1 per cent rate. (Both figures are distorted by the dock strike which started in December 1968 and caused both imports and exports to decline in the fourth quarter.)

Employment growth was rapid in the December to April period. Payroll employment increased at a 4 per cent annual rate from December to April compared with a 3.4 per cent rise in the previous year, and a 2.2 per cent rate for the 1957-67 period. Employment has been increasing faster than population of working force age, which is estimated to be increasing at a 1.6 per cent rate. 


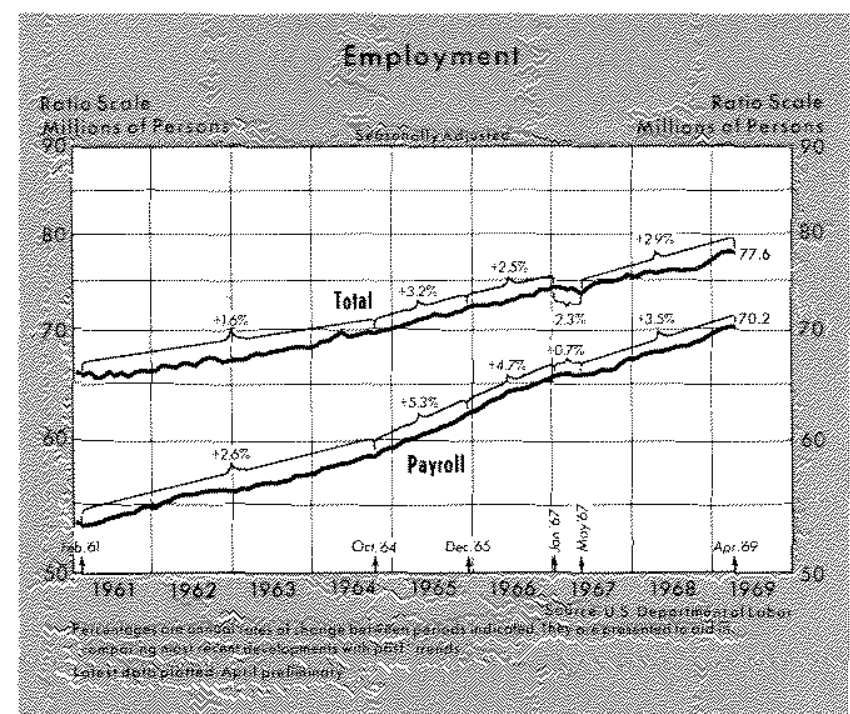

Industrial production increased at a 4.3 per cent rate during the first three months of 1969 , compared to about a 4 per cent rise in the previous year. The production of consumer goods, iron and steel contributed substantially to the first quarter rise. The production of automobile assemblies in the first quarter was down slightly from the end of last year.

\section{Sismonary}

Federal budget actions have become much less expansionary since mid-1968, but there is little likeli. hood of additional fiscal restraint in the remainder of 1969. Reduced growth of several monetary aggre- gates indicated some monetary restraint in the first four and a half months of 1969. Even though the money stock rose sharply in early April, it subsequently declined so that by early May it was up at only about a 2 per cent rate from December.

The advance of spending continues to contribute to price inflation. With fiscal actions scheduled to provide little added restraint in 1969 , limitation on monetary growth appears to be the key to the deceleration of total spending and, ultimately, prices.

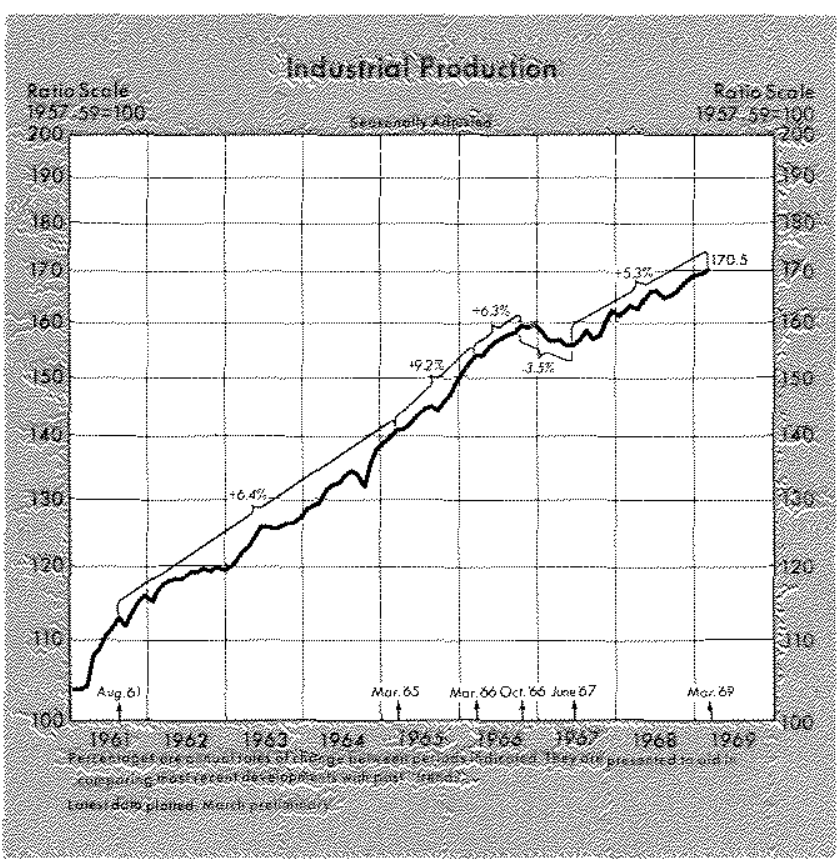

急

UBSCRIPTIONS to this bank's REvIEw are available to the public without charge, including bulk mailings to banks, business organizations, educational institutions, and others. For information write: Research Department, Federal Reserve Bank of St. Louis, P. O. Box 442, St. Louis, Missouri 63166. 